\title{
Plyushch says protest
}

The Soviet Union recently released Leonid Plyushch, the Ukrainian mathematician held for over three years in Dnepropetrovsk penal mental hospital. Vera Rich reports

"I consider that the scientists of the west should protest in an organised manner and publicly against the campaign in the Soviet Union against dissidents, and against prisons, camps and penal psychiatric institutions". This statement has come from Leonid Plyushch, who warmly acknowledges the help of the western academic community in effecting his release from the hospital following the granting of an exit visa in January. He told Nature that he thought pressure from Western scientists was "one of the active factors which assisted my release".

In Plyushch's case, a two-pronged attack on the Soviet authorities was mounted on his behalf-on the one hand by mathematicians and cyberneticists (his professional colleagues), and on the other by psychiatrists, who saw his continued incarceration and the massive doses of drugs to which he was subjected as a blot upon their profession. The mathematicians' campaign followed what has by now become a standard pattern-appeals to the Soviet authorities, proposals to elect Plyushch as a member of eminent mathematical bodies and a concerted effort to keep his case before world opinion. The psychiatrists' campaign was a more complex matter. They were not only concerned with effecting Plyushch's release; they also felt that his commital impugned the honour of their profession. While working to secure his release, they therefore sought a reversal of the diagnosis. This diagnosis stated, apparently on the basis of his criticism of Soviet "state capitalism" (Plyushch's term), his defence of his native Ukrainian culture, and his signature on a petition to the United Nations, that he was suffering from "sluggish schizophrenia" and "reformism"--diseases which, as yet, the psychiatric profession elsewhere does not acknowledge.

Plyushch himself has offered two possible reasons for his committal to the psikhushka rather than to an ordinary prison or camp: firstly, he refused to answer the interrogators' questions, "because I considered, and I told them so, that the KGB is an anti-Soviet, anti-Communist, anti-constitutional organisation"; secondly, "because they knew that in court I would speak from a Communist position and that nothing would happen in court to show that I was an antiSoviet person". Since it appears to be current Soviet policy to present all separatism in the Union Republics as inspired by fascism and international capitalism, this would have been extremely embarrassing.

Plyushch's ideal for his native Ukraine is an independent socialist state on the Dubcek model-or, at the very least, a reversal of the policy of Russification of higher education and learning, which since the decree on education of November 1958 has $A$ gradually introduced Russian as the universal language of the learned professions throughout the Soviet Union. This has in some cases reduced formerly important learned journals into little more than overflow outlets for Moscow publications, and has undermined the very promising lead which, fifteen years ago, the Ukrainian SSR was making in Plyushch's own field of cybernetics.

\section{Soviet response}

In belated response to the campaign by bodies like the Royal College of Psychiatrists, the Soviet authorities, in the person of Dr Snezhnevskii of the Serbskii Institute of Psychiatric Medicine in Moscow, countered finally with accusations of non-professional conduct against the Royal College, which had mentioned "patients" by name. This particular correspondence between the Royal College and Snezhnevskii has not yet been concluded, but it is worth noting that the College only voiced its protests after appeals to world opinion from Plyushch's family and the families of other "psychiatric" prisoners; moreover, an official at the Soviet embassy in Paris had himself divulged names of internees (including that of Plyushch) when he claimed (in a communication to the French mathematician Henri Cartan) that Western psychiatrists who were shown the relevant documents at the Serbskii Institute had all agreed that the persons in question were ill at the time of detention (each of the psychiatrists concerned, who included Dr Denis Leigh, the Secretary General of the World Psychiatric Association, and an ex-President of the American Psychiatric Association, publicly denied this later).

With Plyushch's release, the Soviet Embassy in London has made a determined stand to prove that, even if Plyushch were now sane (as three

\section{Sorry, for copyright reasons some images on this page may not be available online}

\section{Leonid Plyushch: released}

Western psychiatrists-Drs Low-Beer, Sluga and Ferdiere-have declared), he was at the time of his committal mentally ill. Soviet News, the official embassy "hand-out", presents his case as a cure; his mental health is said to have "improved lately", "as a result of treatment". His release is thus presented as a triumph for Soviet psychiatry. To reinforce this impression Soviet News also carries an interview with Denis Leigh. General in its content, in its present context it could be misconstrued as supporting the Soviet viewpoint on Plyushch.

Although the Plyushch case could now be considered closed, the evidence he has brought with him does reopen certain issues for Western scientists. They have long known of the Soviet use of drugs such as haloperidol, sulfazin and triftazin (stelazin) as a means of repression, and what now emerges from Plyushch's evidence is the number of "patients" involved. Plyushch says that he has "almost no information" about other psychiatric hospitals, and he understands that "things are a bit better" in them. But Dnepropetrovsk, he says, is the worst, and he reports that some 60 dissidents, and not the few originally thought, are at present confined there. He stresses the problem that "in a psychiatric prison, a person degenerates intellectually".

Since it is among the intellectuals that the dissident movement in all its varieties has taken the strongest hold, Plyushch's evidence seems certain to provoke considerable concern and disquiet among the world scientific and academic community as a whole. 